\title{
The Impact of Firm Performance on Executive Compensation in France
}

\author{
Amarou Yamina \\ University of Mascara, Algeria
}

Professor Bensaid Mohamed

University of Sidi Bel abbes, Algeria

Doi:10.5901/mjss.2017.v8n2p63

\begin{abstract}
The purpose of this article is to model the executive compensation in France. From a sample of 90 companies included in the SBF 120 over 2004, we examine whether there is a significant link between the overall executive compensation and corporate performance, and then determine the relationship between the fixed and variable part of the compensation with performance. Our findings highlight in particular the level of total executive compensation that is linked with relatively improved performance. And clearer, the pay of executive increases with the increase of financial performance, whereas, the bonus depends on level of accounting performance. The grant of options to executive is relatively linked to the financial performance of the enterprise level.
\end{abstract}

Keywords: CEO compensation, Agency theory, Pay-Performance.

\section{Introduction}

The remuneration policy as a major component of corporate governance is one of the most important factors in the success of the company (Jensen and Murphy, 1990a). Several works on this remuneration were conducted in the US and European contexts. The theoretical reference adopted by most of the works is the agency theory. According to this theory, the executive compensation policy is seen as a governance mechanism acting to resolve conflicts of interest between management and shareholders and improve business performance.

In this sense, Jensen and Murphy (1990) propose a political explanation to the insensitivity of performance-related pay. It is true that legislative intervention aims to strengthen the transparency of executive compensation by reducing the problem of information asymmetry. However, this legislative intervention would have resulted in a weakening of the sensitivity of pay to performance (Jensen and Murphy, 1990).

The choice of the French context may be interesting for two reasons. First, few studies have focused on executive compensation in France. This is explained by the low number of available data to recent developments in corporate governance (Alcouffe, 2007). Indeed, in recent years, laws and codes of governance and conduct have succeeded. Thus the NRE Act of 15 May 2001 now requires listed companies to publish the amounts of their leaders including all fringe benefits and stock options. This law has been complemented by the Breton Act of 26 July 2005 which requires listed companies to include all elements of executive compensation in their management reporting. The primary goal of this regulation is to increase transparency by encouraging companies to report information on governance and especially executive compensation, and to prevent unjustified exaggerations in this regard.

In addition, Gomez-Mejia and Wiseman (1997) identified more than 300 studies, but the number of studies is much more important in recent years and especially since the bubble burst "Internet" in 2000. These studies were carried out mainly in Anglo-Saxon countries, while Cordeiro and Veliyath (2003) note that these studies obtained on the compensation of US executives are inadequate and should be extended and validated in an international context to be 
generalized. Thus, we propose to extend the analysis of the impact of performance on executive pay of linFrench companies. This context may be interesting to the extent that it has special features in terms of corporate governance institutions (La Porta et al., 1999).

This work has the purpose to examine the impact of performance on executive compensation in France. From a sample of French listed companies, we wonder about the impact of the financial and accounting performance on the level of executive pay. By emphasizing the theoretical framework of the agency, we expect that the establishment of a high level of performance allows improving the level of compensation awarded to company executives.

This article is structured in three parts. The first section summarizes the literature based on the theory of the agency and the sensitivity of pay to performance. The second part outlines the methodology deployed. The latter concerns a sample of 90 French listed companies of the SBF 120 for 2004. The analysis of our results is presented in the last part.

\section{Literature Review}

\subsection{The agency theory and compensation plans}

In the Anglo-Saxon model of corporate governance, the famous principal-agent theory (Jensen and Meckling, 1976; Fama and Jensen, 1983) states that these (self interest) managers cannot always perform their duties solely in the interests of the shareholder. And this conflict of interest does not come without cost. Jensen and Meckling (1976) presented the agency conflict as a conflict between management and shareholders. Habib (2005) found that the average corporate stores of the best results of his peers were about 1.432 billion dollars.

Several mechanisms may, therefore, compel and encourage managers to perform their tasks. Consequently, such a governance mechanism is the design of an appropriate incentive program to align the interests of executives with those of shareholders. Incentives include provision of compensation based on performance as bonuses and stock options. Executive compensation is typically divided into a fixed part and a variable part, based on their performance. This variable portion is based on the short-term performance (often based on the net income and paid out as a bonus) and another dependent on the long-term performance (often based on the share price that is paid by the granting stock options) (Scott 2000).

\subsection{Executive compensation and corporate performance}

In the agency theory, the problem is to create an incentive structure that aligns the interests of shareholders with the benefits of the executives. To achieve this, a remuneration agreement is generally offered to executives to increase shareholder's wealth (Jensen and Murphy (1990)). In this context the performance improves and the officers receive additional compensation. So the remuneration of contract aims to reward executives so that they strive to maximize business performance and shareholder wealth.

There is no general consensus, in literature, on the relationship between pay and performance. Indeed, existing empirical studies report conflicting evidence as to the impact of the performance of the company on executive pay; while several studies have found a positive relationship between the level of executive pay and performance ( Crespi-Cladera and Gispert (2003)); others have found no relationship between executive pay and performance (Dogan and Smith (2002)).

Kato and Kubo (2005) examine the place between CEO pay and company performance in Japan, using data from the period 1986-1995. They find that the remuneration in cash (salary + bonus) is sensitive to performance, particularly on accounting measures. However, the performance of stock market seems less important in determining the remuneration of executive compensation because until 1997 the use of share purchase options to officers has been banned in Japan. While Makinen (2005) uses data from the period 1996-2002. He argues that the relationship between the total compensation of the CEO and financial performance is important, and it follows that there is no relationship between the remuneration of chief executive and accounting performance (ROA).

Our first hypothesis will be devoted to the sense that the past performance (in terms of accounting and market measures) positively influences the total executive compensation.

All by referring to previous studies, we expect: business.

H1: The performance of the company positively influences the fixed remuneration of the short-term leader in the

H2: The performance positively affects the short-term variable compensation leader. 
H3: the performance of the company positively influences the part of stock options.

First we regressed the total compensation (salary + bonus + option + stock of other forms of remuneration) based on the financial and accounting performance.

REM $=a 0+a 1 Q T O B I N+a 2$ CONCEN+a3 SIZE $+a 4 L E V+a 5$ SECTOR+ $\xi$

REM $=a 0+a 1$ ROA $+a 2$ CONEN $+a 3$ SIZE $+a 4$ LEV $+a 5$ SECTOR $+\xi$

Then we made these models:

SALARY $=a 0+a 1$ QTOBIN $+a 2$ CONEN $+a 3$ SIZE $+a 4$ LEV $+a 5$ SECTOR $+\xi$

SALARY $=a 0+a 1$ ROA + a2 CONCEN $+a 3$ SIZE $+a 4$ LEV $+a 5$ SECTOR $+\xi$

BONUS $=a 0+a 1$ QTOBIN $+a 2$ CONCEN $+a 3$ SIZE $+a 4$ LEV $+a 5$ SECTOR $+\xi$

BONUS $=a 0+a 1$ ROA $+a 2$ CONCEN $+a 3$ SIZE $+a 4$ LEV $+a 5$ SECTOR $+\xi$

And finally, we are going to test our last hypothesis regarding the relationship between stock option and performance:

$$
\begin{aligned}
& \text { STOCK }=a 0+a 1 \text { QTOBIN }+a 2 \text { CONCEN }+a 3 \text { SIZE }+a 4 \text { LEV }+a 5 \text { SECTOR }+\xi \\
& \text { STOCK }=a 0+a 1 \text { ROA }+a 2 \text { CONCEN }+a 3 \text { SIZE }+a 4 \text { LEV }+a 5 \text { SECTOR }+\xi
\end{aligned}
$$

\section{Methodology}

\subsection{Sample Description}

Our initial working sample consists of 90 companies listed on the French stock market index constituent of the SBF 120 for 2004. The selection of the companies in our sample was done randomly and simply. The primary source of data is the annual reports and reference materials published annually by the companies concerned.

\subsection{Definition of variables}

\subsubsection{The dependent variables:}

The total amount of the remuneration (REM) received by the executive during the reference year 2004 was obtained from the analysis of annual reports; we use the natural logarithm of executive compensation. This amount of compensation is understood as including all short-term factors and long-term compensation that were disclosed in annual reports. This is generally the base salary, bonuses, benefits in kind, the granting of share purchase option ... ect.

The base salary variable (SALARY) is the logarithm of the salary of executives in the company. The use of the logarithm is consistent with previous studies (Ke et al. 1999). The salary value is collected from the company's annual reports. Also the bonus value is collected from annual reports; we measured them by the logarithm of these values.

Finally, stock option as the variable part in executive compensation. Several researches did not take this variable into account in its work on executive pay, as measured by the Black and Scholes formula. In our work we took it as a binomial variable if the company grants stock options this year its value is 1 if not its value is 0 .

\subsubsection{The independent variables}

We measured the market performance by the Tobin $Q$ ratio and accounting performance measurement by the ROA. This measure is widely used in the compensation literature (Cregg and Machin Szymanski 1993 Carpenter and Sander 2001 Makinen 2005).

For the construction of our model, we used four control variables from empirical studies to date:

1. Ownership structure: The ownership of controlling shareholders (CONCEN) is the property of shareholders holding more than $5 \%$ of the company's capital. We chose $5 \%$ as many researchers, such as Mehran (1995), Doucouliagos et al. (2006),

2. Size: We retain well as a measure of size, the following variable: $\operatorname{SIZE}=\operatorname{Ln}$ (total assets).

3. Debt: The measurement of this variable (LEV) in our study is by debt ratio = total liabilities / total assets.

4. Sector: We divided the companies in our sample into two major lines of business, and to do this we used a dichotomous variable coded 1 for business services and 0 for the industrial sector. 


\section{Results}

\subsection{Description of variables}

As it is known the price of the shares is highly volatile, due to this, we observe that the financial performance shows a standard deviation of 1.56 is very high compared to other variables.

Table 1 also shows that the accounting performance average is very low compared to the financial performance, which leads us to conclude that the companies in our sample based on the allocation of shares in the stock market.

As known to French companies, ownership concentration shown in Table 1 is relatively small. The average percentage of capital held by controlling shareholders is equal to $29.64 \%$.The standard deviation of this variable is 0.0047 , which shows that this is non-volatile relative to other. The absence of the majority of shareholders increases the level of executive compensation.

Regarding the characteristics of business variables, we observe that the average size of the company equal to 6.39 , which vary between 0.9 and 13.81 . We also note that the percentage of debt held by companies is around $26.75 \%$ with a standard deviation of 0.16 , implying that companies that we chose do not rely much on external resources (Debt) in financing its investments.

Table 1. Descriptive statistics of the explanatory variables and the dependent variables

\begin{tabular}{|c|c|c|c|c|c|}
\hline Variables & Mean & SD & Variables & Mean & SD \\
\hline QTOBIN & 1.73542 & 1.56894 & REM & 5.583583 .3690 & 0.6464121 .61147 \\
\hline ROA & 0.07174 & 0.28102 & SALARY & 6.206234 .73251 & 0.626492 .13254 \\
\hline CONCEN & 0.29640 & 0.0047 & BONUS & 5.948741 .7990 & 0.61034 .51623 \\
\hline SIZE & 6.39391 & 0.67534 & & & \\
\hline LEV & 0.26751 & 0.16424 & & & \\
\hline
\end{tabular}

In this Table, we have the mean bonus in our sample is $1.799,160$ euro, with a high standard deviation of 4.5162 . This indicates that the bonuses paid to executives in listed companies in France is very volatile compared to other components of total compensation, and we noticed a lack of this bonus in some companies in our sample which indicates that the bonus accounts are not an important part of the remuneration compared to the leaders of these companies. Also, the executive pay appears equal to average 4.732 million euro with a standard deviation a low of 2.1325 orders. This indicates that executive pay is varied in our sample firms.

The remuneration is 3.36902 million euro on average with a standard deviation of 1.6114 . These summary statistics are consistent with previous studies of Core et al. (2003).

According to the table we find that among 90 research companies, there are 76 companies attribute the granting of stock options to executives.

\subsection{Interpretation of results:}

\subsubsection{The compensation and performance}

The results of the total compensation of both models (Table 2) indicate that the models applied in our study sample are globally significant. For example, for the first model, the adjusted $\mathrm{R}^{2}$ value of 0.2866 indicates that $28.66 \%$ of variation of total compensation is explained by the variation in the explanatory variables used in this model.

The coefficient of accounting performance is positive $(0.29)$ and significant at $1 \%$. When the performance measure used is financial (estimated by the Q-Tobin), the association between the total compensation and the company's performance is positive and strong significance, it is significant at the $1 \%$. This result corroborates our initial hypothesis, according to which the increase in financial performance allows shareholders to pay their executives, so the total executive pay increases. Our result is similar to those found by Finkelstein and Hambrick (1989), Fisher and Govinrajdan (1992), Makinen (2005).

In both regression models, we find that our control variables remain insignificant except the variable of ownership structure. We find that this governance variable is significant at the $1 \%$, but its positive coefficient. This raises a positive and very significant between the concentration of the majority shareholders and the level of total executive compensation in listed companies in France. But theoretically, a large concentration of the majority of shareholders on the company's 
capital promotes to exercise more control over the executive, which limits the ability to influence executive remuneration (Shin (2005).

In summary, we confirmed our first hypothesis based on the French market. Our results thus confirm the predictions of agency theory according to which the adoption of the remuneration system motivates leaders to work harder. It involves a performance improvement, and therefore, leaders receive adequate compensation.

Table 2: The compensation and performance

\begin{tabular}{|c|c|c|c|c|c|}
\hline Variables & Coefficients & T-student & Variables & Coefficients & T-student \\
\hline Constant & 3.28273 & $4.6693^{\star * *}$ & Constant & 3.36525 & $4.6931^{\star * *}$ \\
\hline ROA & 0.29075 & $2.6693^{\star * *}$ & QTOBIN & 0.27252 & $2.4888^{\star * *}$ \\
\hline CONCEN & 0.52450 & $2.4541^{* * *}$ & CONCEN & 0.49991 & $2.3336^{* *}$ \\
\hline SIZE & -0.02002 & -0.4729 & SIZE & -0.00783 & -0.1833 \\
\hline LEV & -0.01954 & -0.0823 & LEV & 0.02119 & 0.0890 \\
\hline SECTOR & 0.47873 & 1.3762 & SECTOR & 0.32177 & 0.3726 \\
\hline$R^{2}=0.338570$ & & & $R^{2}=0.3295$ & & \\
$R^{2}$ ajust $=0.28667$ & & $R^{2}$ ajust $=0.277$ & & \\
Fisher $=(2.67)^{\star * *}$ & & & Fisher $=(2.47)^{\star *}$ & & \\
\hline
\end{tabular}

${ }^{* * *}$ Significant at the $1 \%$ level, ${ }^{* *}$ significant at the $5 \%$ level, ${ }^{*}$ significant at the $10 \%$ level.

\subsubsection{Fixed compensation (salary) and corporate performance}

The first model applied to show the correlation between pay and the accounting performance is generally not significant, we find that the statistics of Fisher $\mathrm{F}$ somewhat significant at $10 \%$ threshold. Thus, the adjusted $\mathrm{R}^{21}$ value is very low in the order of 0.03103 ; this indicates that independent variables do not explain our dependent.

By cons, our second model that tests the association between pay and financial performance is, in general, significant with a high value of coefficient of determination equal to $\mathrm{R}^{2} 2=53.21 \%$ and Fisher statistics $\mathrm{F}$ (significant at $1 \%$ ). In addition, the adjusted $R^{2} 2$ value is high compared to the first model in the range of 0.48765 ; this value indicates that the explanatory variables we chose explain the executive pay levels in the companies of our sample.

In keeping with previous research, we find that a positive relationship is significant between executive pay and financial performance, this result supports our original hypothesis that predicts a positive association between the level of pay of executives and financial performance, this result was found by Abowd (1990), Makinen (2005).However, the concentration of the majority shareholdings is positively and significantly related to executive pay levels based on financial performance, this result is difficult to explain.

Furthermore, examination of tested statistics allows us to confirm our underlying assumption that executive salaries are linked to performance, specifically in financial performance.

Table 3: Fixed compensation (salary) and corporate performance

\begin{tabular}{|c|c|c|c|c|c|}
\hline Variables & Coefs & T-student & Variables & Coefs & T-student \\
\hline Constant & 5.312698 & $7.569^{* * *}$ & Constant & $4.07 \mathrm{E}-14$ & $7.6547^{\star * *}$ \\
\hline ROA & 0.135862 & 1.2499 & QTOBIN & 1.000000 & $1.23 \mathrm{E}^{\star \star \star}$ \\
\hline CONCEN & -0.076833 & -0.3605 & CONCEN & $1.14 \mathrm{E}-15$ & $0.7201^{*}$ \\
\hline SIZE & -0.036326 & -0.8594 & SIZE & $-8.97 \mathrm{E}-17$ & -0.2834 \\
\hline LEV & -0.017627 & -0.0744 & LEV & $-4.42 \mathrm{E}-16$ & -0.2507 \\
\hline SECTOR & 0.735624 & $2.1183^{* *}$ & SECTOR & $9.49 \mathrm{E}-15$ & $3.5701^{\star \star \star}$ \\
\hline $\begin{array}{c}R^{2}=0.0860 \\
R^{2} \text { ajust }=0.031 \\
\text { Fisher }=(1.563)^{*}\end{array}$ & & & $\begin{array}{c}R^{2}=0.53214 \\
R^{2} \text { ajust }=0.487 \\
\text { Fisher }=(3.26)^{* * *}\end{array}$ & & \\
\hline
\end{tabular}

\subsubsection{Incentive compensation and company performance}

\subsubsection{The variable remuneration (bonus) and corporate performance}

The regression results of the two models concerning the link between bonus and performance with its two measures are 
not similar. The first model is significant given its coefficient of determination and $\mathrm{F}$ Fisher statistics (significant at the $1 \%$ level), the coefficient of determination is very high $\left(R^{21}=0.8856\right)$, with a value equal to $0.8765 R^{2}$ adjusted. In contrast, in the second model the link between bonuses and financial performance is generally not significant.

Consistent with our predictions, we affirm that only a part of our third hypothesis is positive since the association was significant only between the bonus and accounting performance. In keeping with some previous research, they found that the carrying performance is more related with a financial incentive pay in cash (Lambert et al. (1987), Sudipta et al. (2006), Davila and Penalva (2005).

Table 4: The variable remuneration (bonus) and corporate performance

\begin{tabular}{|c|c|c|c|c|c|}
\hline Variables & Coefficients & T-student & Variables & Coefficients & T-student \\
\hline Constant & $-3.09 \mathrm{E}-14$ & $-6.863^{* * *}$ & Constant & 5.198201 & $7.299^{* * *}$ \\
\hline ROA & 1.000000 & $1.431^{* \star *}$ & QTOBIN & 0.135884 & 1.2494 \\
\hline CONCEN & $-1.13 \mathrm{E}-15$ & -0.827 & CONCEN & -0.16570 & -0.7788 \\
\hline SIZE & $7.29 \mathrm{E}-17$ & 0.2689 & SIZE & 0.013792 & 0.3250 \\
\hline LEV & $-6.22 \mathrm{E}-16$ & -0.4093 & LEV & 0.141402 & 0.5981 \\
\hline SECTOR & $-9.01 \mathrm{E}-15$ & $-4.048^{* * \star}$ & SECTOR & 0.068388 & 0.1918 \\
\hline$R^{2}=0.8856743$ & & & $R^{2}=0.036876$ & & \\
$R^{2}$ ajust $=0.87654$ & & $R^{2}$ ajust $=0.0211$ & & \\
Fisher $=(4.19)^{* \star}$ & & & Fisher $=(0.635)$ & & \\
\hline
\end{tabular}

\subsubsection{Variable compensation (stock option) and performance}

The results of our study indicate that the coefficient of performance measurement accounting is negative and significant, and even the coefficient of performance measurement Financial is positive and significant in the second model, this indicates that the company acts on the part variable long-term compensation to encourage leaders to make more effort leads to the company's financial performance improvement. We note that the performance market is significant at a risk level of $1 \%$ in the equation options, while in the equation bonus, we find that the performance market is not significant. This difference can be explained by the different nature of the two forms of compensation: the options are the most important part of compensation since they act directly on the wealth of leaders which is not the case for the bonus which is an additional monetary value that corresponds to the level of the accounting business performance. So this result affirms our last hypothesis.

Table 5: Variable compensation (stock option) and performance

\begin{tabular}{|c|c|c|c|c|c|}
\hline Variables & Coefficients & T-student & Variables & Coefficientts & T-student \\
\hline Constant & $3.20 \mathrm{E}-15$ & $5.314^{* * *}$ & Constant & $3.59 \mathrm{E}-16$ & $-7.34^{* * *}$ \\
\hline ROA & $-6.88 \mathrm{E}-16$ & $-7.376^{* \star *}$ & QTOBIN & $5.48 \mathrm{E}-17$ & $8.276^{\star * *}$ \\
\hline CONCEN & 1.000000 & $5.46^{* * *}$ & CONCEN & $1.07 \mathrm{E}-16$ & 9.33 \\
\hline SIZE & $-8.10 \mathrm{E}-18$ & -0.223 & SIZE & $2.14 \mathrm{E}-17$ & 0.0000 \\
\hline LEV & $-5.27 \mathrm{E}-17$ & -0.2593 & LEV & $1.19 \mathrm{E}-16$ & 0.0000 \\
\hline SECTOR & $1.13 \mathrm{E}-15$ & $3.7798^{* * *}$ & SECTOR & $1.80 \mathrm{E}-16$ & 0.000 \\
\hline $\mathrm{R}^{2}=0.987651$ & & & $\mathrm{R}^{2}=0.8856743$ & & \\
$\mathrm{R}^{2}$ ajust $=0.897$ & & & $\mathrm{R}^{2}$ ajust $=0.876$ & & \\
Fisher $=(6.34)^{* * *}$ & & & Fisher $=(4.19)^{* * *}$ & & \\
\hline
\end{tabular}

\section{Conclusion}

This article was devoted to the empirical study of the relationship between the performances and exogenous variables on the executive compensation policies.

The study in question is based on a sample of 90 French companies included in the SBF 120 index over a period of one year. This method was conducted using a multiple regression technique to translate the relationship between executive pay and company performance.

From this study, we showed the contradiction of previous studies to the impact of performance on total executive compensation and also to the impact of performance on executive compensation modes. 
Furthermore, this study indicates that the level of total executive compensation is linked with relatively improved performance. And clearer, executive pay increases with the increase of financial performance, whereas, the bonus depends on level of accounting performance.

The number of grant of the options is relatively linked to the financial performance of the enterprise level.

Regarding the control variables only the Company's activities sector positively influences the level of remuneration.

\section{References}

Alain Schatt (2000), « Quel avenir pour l'information comptable ? » revue de finance, 9-10

Albouy, M., (2004), "Rémunération des dirigeants et performance boursière", Analyse Analyse Financière, $n^{\circ} 10$, pp.42-44.

Bebchuk, L,. Fried, J., (2003), "Executive compensation as an agency problem", Journal of Economic Perspectives, vol.17, n-3, pp.7192.

Bebchuk, L., Fried, J., (2004), "Pay without performance, the unfilled promise of executive compensation", Harvard University Press.

Bergstresser, D., Philippon, T., (2006). "CEO incentives and earnings management". Journal of Financial Economics 80, 511-529.

Clarkson,P., Nichols,S., Walker,J,( 2005) "Evidence on the Link between CEO Remuneration and Company Performance", The University of Queensland Brisbane, Qld. Australia 4072.

Core, J., Guay, W. et Larcker, D., (2002), "Executive equity compensation and incentives : a survey", Working Paper, University of Pennsylvania.

Doucouliagos,H. Askary, S. Haman,J. (2006), "Directors' Remuneration and Performance Australian Banking”, Faculty of Business and Law.

Frydman, C., Saks, R, E,. (2007), "Executive Compensation: A New View from a Long-Term Perspective, 1936-2005”, Working Paper.

Hall, B., Liebman, J., (1998). "Are CEOs really paid like bureaucrats?", Quarterly Journal of Economics 113, 653-691.

Jensen, M., Meckling, W., (1976). " Theory of the firm: managerial behavior, agency costs and ownership structure ", Journal of Financial Economics 3, 305-360.

Jensen, M.C. and Murphy, K.J. (1990). "Performance pay and top-management incentives". Journal of Political Economy, 98(2): 225264.

Kaplan, S.N., (1994), "Top executive rewards and firm performance: a comparison of Japan and the U.S.", Journal of Political Economy, vol.102, pp.510-546.

Kato, T. et Lee,J.H., (2004), "Executive Compensation and Firm Performance in Korea", Working Paper 04-0.

Kato, T., Kubo, K., (2006). "CEO compensation and firm performance in Japan: evidence from new panel data on individual CEO pay", Journal of Japanese and International Economies 20, 1-19.

Main, B.G.M., Bruce, A. and Buck, T. (1996). "Total board remuneration and company Performance". Economic Journal, 106(439): 16271644.

Mehran, H. (1995). "Executive compensation structure, ownership, and firm performance", Journal of Financial Economics, vol.38, pp. 163-184.

Murphy, K. (1998). "Performance Standards in Incentive Contracts", working paper, University of Southern California.

Murphy, K., (1999). "Executive Compensation", Handbook of Labor Economics, Vol. 3. North-Holland: Amsterdam.

Parthasarathy, P. Menon, K., Bhattacherjee, D., (2006), "Executive Compensation, Firm Performance and Corporate Governance: An Empirical Analysis", Indian Institute of Management Calcutta.

Peter L. Swan., (2006), "Does Executive Compensation Disclosure Alter Pay at the Expense of Incentives?", University of New South Wales and University of Hong Kong.

Tosi, H,. Werner, S,. Katz, J,. Gomez-Mejia, L., (2000). "How much does performance matter? A metaanalysis of CEO pay studies". Journal of Management 26, 301-339.

Vigliano,M,H. (2007), « Contrôle du Conseil d'administration et rémunération des dirigeants: réplication de la recherche de Boyd (1994) au contexte français ». 